\title{
Developing a Taxonomic Framework of Security Methods for Security Management and Information Resource Management
}

Yejun Wu

Louisiana State University and Agricultural \& Mechanical College, wuyj@lsu.edu

Follow this and additional works at: https://digitalcommons.usf.edu/jss

pp. 64-77

\section{Recommended Citation}

Wu, Yejun. "Developing a Taxonomic Framework of Security Methods for Security Management and Information Resource Management." Journal of Strategic Security 13, no. 2 (2020) : 64-77.

DOI: https://doi.org/10.5038/1944-0472.13.2.1787

Available at: https://digitalcommons.usf.edu/jss/vol13/iss2/4

This Article is brought to you for free and open access by the Open Access Journals at Digital Commons @ University of South Florida. It has been accepted for inclusion in Journal of Strategic Security by an authorized editor of Digital Commons @ University of South Florida. For more information, please contact digitalcommons@usf.edu. 


\title{
Developing a Taxonomic Framework of Security Methods for Security Management and Information Resource Management
}

\begin{abstract}
People who are concerned with security (such as security professionals) are naturally interested in methods of achieving security. This paper proposes an approach to creating a taxonomic framework of security methods. The taxonomic framework is developed using facet analysis based on a tetra-facet model of security, which identifies four facets of security: subject/scope of security, object of protection, source of insecurity, and method of protection. The taxonomic framework of security methods is created by combining two of the facets: source of insecurity and method of protection. The taxonomic framework of security methods can be integrated with the taxonomic framework of security (which was developed in a previous study), and can be used for security management and the management of information resources related to security and security methods.

\section{Acknowledgements}

The author would like to thank the anonymous reviewers for their constructive suggestions and comments, which have been incorporated into the article.
\end{abstract}




\section{Introduction}

The human society has been getting more and more concerned with security. News about security is frequently heard on media. For example, on May 16, 2019, the U.S. Department of Commerce applied export control restrictions to China telecommunications equipment maker Huawei Technology Ltd. and 68 of its affiliates deemed a risk to U. S. national security. ${ }^{1}$ This is an example of an attempt to use political and economic methods to achieve national security. On November 1, 2019, Russia passed a new internet sovereignty law that grants the Russian government the ability to disconnect the entire country from the global internet in the event of a national emergency or foreign threat, such as a cyberattack. ${ }^{2}$ This is an example of an attempt to use technological and political methods to achieve national security. These examples raise a question: What methods can be used to achieve security?

Security in this article is a concept related to threat, safety, and protection. People who are concerned with security are probably more interested in methods of protecting security (or security methods). In a previous study, the author collected existing classification snippets of security from knowledge organization systems such as Library of Congress Classification (LCC), Library of Congress Subject Headings (LCSH), and ACM Computing Classification System (ACMCCS). 3 The author also inferred classification snippets of security from functional components of major government agencies and international organizations with security management tasks (such as the Department of Homeland Security, the Social Security Administration, and the World Bank), and other sources. 4 It was found that there is no comprehensive taxonomy of security methods except in the information security sub-domain. 5 LCC and LCSH contain fragmented taxonomies of security, but do not contain any section of security methods. ${ }^{6}$ The ACM Computing Classification System has a Security and Privacy section, which has the following major subcategories: Cryptography, formal methods, and theory of security, security services, intrusion/anomaly detection, and malware mitigation, security in hardware, systems security, network security, database and storage security, software, and application security, human and societal aspects of security and privacy.7 It includes some information security-related subject terms (such as system security, network security) and some security methods (such as cryptography, formal methods, and security 
services, which further include authentication, access control, and authorization). In a previous study, the author identified method of protection as a facet of security, and developed an incomplete, generic list of these methods, including physical method, economic method, financial method, technological method, military method, cultural/psychological method, administrative/legal/political method, and comprehensive method. ${ }^{8}$ These findings and resources lay the foundation for the proposed approach to developing a taxonomic framework of security methods.

The goal of this research is to develop a taxonomic framework of security methods based on the author's previous studies. ${ }^{9}$ The taxonomic framework can be used for the management of security methods and information resources about security methods. The significance of the study is introduced in the next section.

\section{Significance of the Study}

Security is an ambiguous term and there is not a precise and universally accepted definition of security..$^{10}$ Various aspects of security are studied in various disciplines and application domains, and the community of security studies has greatly expanded the scope of security in the past thirty years. ${ }^{11}$ As a result, there is no comprehensive classification scheme of security. "Addressing security issues can ultimately boil down to a problem in classification. The goal is to put the problem into general categories ... of threats and then identify the risk factors for each category." 12 A classification scheme of security or threats is needed when addressing security issues. In an earlier article, the author introduced an approach to developing a comprehensive taxonomy of security, and proposed to develop a taxonomy of security methods in a future study. 13 However, due to the lack of a universal definition or understanding of security, a global taxonomy of security terms or security methods is certain to be inadequate in one way or another. Therefore, this article aims to propose a taxonomic framework of security methods, and any security practitioner or researcher can use this framework to develop a taxonomy of security methods based on their subjective understanding of security.

This research illustrates no comprehensive taxonomy of security methods. Several books can be considered as taxonomic introductions to security methods in government/corporate domains. Hemphill's Modern Security 
Methods introduces methods for protecting personal and business security. ${ }^{14}$ Young's Metrics and Methods for Security Risk Management introduces security methods and standards in government/corporate security domain, including physical security standards for office facilities, standard for fire safety, security standard for the off-site storage of media containing sensitive or proprietary information, and security standard for facilities that process electronic information (data centers). ${ }^{15}$ John Fay's Contemporary Security Management introduces all necessary physical and IT security measures in government/corporate environment. ${ }^{16}$ James Broder and Eugene Tucker's Risk Analysis and the Security Survey shows how to develop and maintain current business contingency and disaster recovery plans to ensure enterprises are able to sustain loss and recover. ${ }^{17}$ It introduces a security survey checklist, including policy and program, organization, control of entry and movement, barriers (fences, gates, walls, etc.), locks and keys, alarms, communications, property control (equipment, material, tools, personal property), emergency planning, and personnel screening.

This study applies facet analysis to the hypernym of a subject term (that is, security) instead of the subject term itself (that is, security methods) in taxonomy development. The taxonomy can be useful for managing information resources about security when security methods are focused, and can be useful for security management since multiple organizations may use certain security methods to manage multiple aspects of security. The users of the taxonomic framework can be organizations (such as government agencies and corporations) that manage all aspects of security, libraries, and information centers that manage information resources about security, and researchers who study security and security methods. Imagine an academic library of a university (such as the National Intelligence University of the United States) that has a special collection of information resources that is related to security methods. A taxonomy of security methods can be useful for the library to organize the collection for information access.

\section{Methodology}

In the previous work on developing a taxonomy of security, the author collected 120 journal articles, book chapters, and online documents that are closely related to security definitions, dimensions, features, methods, 
taxonomies, and classifications from 102 security-related journals and websites. ${ }^{18}$ The author has collected existing classification snippets of security from knowledge organization systems such as Library of Congress Classification (LCC), Library of Congress Subject Headings (LCSH), and ACM Computing Classification System (ACMCCS), or inferred classification snippets of security from functional components of major government agencies and international organizations with security management tasks. ${ }^{19}$ These resources are analyzed to create a list of terms related to security methods.

There are many online resources about Internet security, cybersecurity, data security on the Web. For examples, Chakrabarti and Manimaran proposed a taxonomy of Internet infrastructure security attacks and solutions, and Pekin Insurance proposed 10 data security methods for protecting small businesses. ${ }^{20}$ These small taxonomies are merged into ACMCCS as a sub-category of information security methods.

Facet analysis and a tetra-facet model of security, which was created in the author's previous study, are used to build the taxonomic framework of security methods. ${ }^{21}$ Library scientist S.R. Ranganathan first introduced facet analysis to denote the technique of separating the elements of complex subjects in relation to a set of abstract fundamental concepts. ${ }^{22}$ Facets are homogeneous or semantically cohesive categories, which are used to create term groupings of a subject discipline with a manageable size. ${ }^{23}$ Facet analysis can "provide a framework within which all the various types of terms can be accommodated, together with rules for their combination." 24 Facet analysis is conducted based on Ranganathan's five fundamental categories that can be used to demonstrate the facets of a subject:

- Personality (P, the focal subject),

- Matter (M, the substance, properties or materials of the subject),

- Energy (E, including the processes, operations and activities),

- Space (S, which relates to the geographic location of the subject) and

- Time ( $\mathrm{T}$, referring to the time of the subject). ${ }^{25}$

Inspired by the information security section of ACMCSS, the author can work with the experts in various dimensions of security (such as national 
security, economic security, human development security, international security, military security, environmental security) to develop a security methods taxonomy for each domain. ${ }^{26}$ However, these security dimensions have overlaps. ${ }^{27}$ Therefore, this approach is not flawless. Ranganathan's facet analysis can be used to separate the elements of complex subjects in relation to a set of abstract fundamental concepts. ${ }^{28}$ The elements are called facets, which are homogeneous or semantically cohesive categories. ${ }^{29}$ However, performing facet analysis on security methods will get the generic list of security methods (such as physical method, financial method, political method) when the Matter facet is considered, or a list of specific security implementation methods when the Energy facet is considered. Therefore, the author retreated to the facets of security for a possible solution. ${ }^{30}$

In the previous work, the author found that security is expressed in this pattern: A subject wants to protect objects against sources of insecurity using certain methods, and identified four facets of security:

- Subject/Scope of Security,

- Object of Protection,

- Source of Insecurity, and

- Method of Protection. ${ }^{31}$

Using this tetra-facet model of security to analyze the security methods in the information security domain, the author found that information security methods could be the combination of the Subject/Scope facet of security (which is information) and the technological method facet of Method of Protection. It can also be the combination of the Object of Protection facet of security (which is information or information systems) and the technological method facet of Method of Protection. ${ }^{32}$ Using the Subject/Scope facet of security to develop the taxonomy of security methods is not ideal because different subjects of security (such as nation, organization, family, and individual) may want to use same security methods. Using the Object of Protection facet (such as body, property, governance, economy, food, environment, job, health, energy, information) to organize security methods is a possible solution, but one would need to make a long list of the objects people have and want to protect, and they can also be overlapped. A better solution is to use the Source of Insecurity facet (that is, various kinds of threats, fears, 
vulnerabilities, and risks) to organize security methods because the threats and risks emerging from the Object of Protection are the things that trigger people's security alarms. 33 This solution is consistent with Young's ideas: Since "all security risk issues derive from threats...in analyzing any security problem, the [...] first step is to accurately identify and categorize the set of unique threats." 34 "The quest of the security professional is to understand the spectrum of unique threats and to accurately classify them pursuant to assessing their individual components of risk and then applying mitigation." 35 "The process of developing a risk mitigation strategy begins with identifying the set of unique threats and associated risk factors for each of those threats." 36

The breadth of threats in the modern world of security is wide. "On a high level, these range from the relatively mundane like 'theft' to the more esoteric variety such as chemical, biological, and radiological weapons. If one considers all the variations of each threat, in addition to differences associated with venue, facility type, there are potentially an infinite number of threat scenarios." 37 Listing all security risk scenarios "invites complexity and can lead to confusing, duplicative, and/or wasteful mitigation strategies." 38 Therefore identifying general categories of risks (or sources of insecurity) based on common features is more efficient and informative than listing all specific security risk scenarios, and each category can be effectively addressed by similar mitigation methods. 39 Source of insecurity types is used in the taxonomic framework to represent categories of threats and risks based on common features.

Source of insecurity types includes a wide range of threats, fears, vulnerabilities, and risks, such as war and violence between/within states, weapons proliferation, migration, hunger, infectious disease, environmental degradation, hazards, climate change, poverty, underdevelopment, social inequalities, man-made risks due to modernization (such as financial crisis), and socially-created disasters (such as destruction of water and electricity systems). $4^{\circ}$ Sources of microlevel personal and community insecurity, as well as emotional (vs. physiological) insecurity, can be added in the future. ${ }^{41}$

With the bottom-level terms of security methods and top-level facets for security methods (that is, Source of Insecurity, Method of Protection), a combination of top-down and bottom-up approach is used to develop the 
taxonomic framework of security methods since it is the best practice in taxonomy construction as discussed in knowledge organization literature. $4^{2}$ This approach develops the higher-level categories in the taxonomic framework first, classifies security method terms into lowerlevel categories, and refines the lower-level categories according to the constraints of the higher-level categories.

\section{The Taxonomic Framework of Security Methods and Connection to the Security Taxonomy}

The first four steps of Young's process used to develop a particular security mitigation strategy include the following:

1. "identify the set of unique threats,

2. determine the relevant risk factors that enhance the likelihood or vulnerability components of risk associated with each unique threat [type],

3. establish the full set of controls to address each risk factor,

4. specify the methods necessary to implement each control." 43

Young's control is a set of high-level mitigation measures. The first four steps of the security risk mitigation process can be illustrated as this:

Threat (implies $\rightarrow$ ) Risk (mitigated by $\rightarrow$ ) control (applied by $\rightarrow$ ) method. 44

In this article, Young's threat and risk are integrated into source of insecurity types, Young's control is mapped onto security method type, and Young's method is mapped onto security method instance.

Table 1 shows a small example of the framework of the taxonomy, which is created by combining the Source of Insecurity facet and the Method of Protection facet. The security methods taxonomy can be connected with the security taxonomy framework developed in the author's previous study by adding the Subject/Scope facet and the Object facet. 45 
Table 1. A Snippet of Taxonomic Framework of Security Methods

\begin{tabular}{|c|c|c|c|}
\hline $\begin{array}{l}\text { Source of Insecurity } \\
\text { (Type) }\end{array}$ & Method of Protection & Security Method (Type) & Instance of Security Method \\
\hline \multirow{4}{*}{ Climate Change } & Technological method & Control of emission of greenhouse gases & Renewable energy technology \\
\hline & Economic method & Carbon emission trade & $\begin{array}{l}\text { Chicago Climate Exchange (ceased in } \\
\text { 2010) }\end{array}$ \\
\hline & \multirow[b]{2}{*}{ Legal/political method } & \multirow{2}{*}{$\begin{array}{l}\text { International treaties on greenhouse-gas- } \\
\text { emissions mitigation, adaptation, and } \\
\text { finance }\end{array}$} & Kyoto Protocol \\
\hline & & & Paris Agreement \\
\hline \multirow{6}{*}{$\begin{array}{l}\text { Proliferation of powerful } \\
\text { weapons }\end{array}$} & Physical method & Destruction of weapons & $\begin{array}{l}\text { Destruction of missiles and chemical } \\
\text { weapons in Soviet Union }\end{array}$ \\
\hline & Economic method & Reemployment of weapon scientists & $\begin{array}{l}\text { Employment opportunities for } \\
\text { former weapons scientists of Soviet } \\
\text { Union }\end{array}$ \\
\hline & $\begin{array}{l}\text { Diplomatic method, } \\
\text { military method }\end{array}$ & Counterproliferation & \\
\hline & \multirow{3}{*}{ Legal/political method } & \multirow{3}{*}{$\begin{array}{l}\text { International agreements on control of } \\
\text { weapon proliferation }\end{array}$} & Convention on conventional weapons \\
\hline & & & $\begin{array}{l}\text { Treaty on the Nonproliferation of } \\
\text { Nuclear Weapons }\end{array}$ \\
\hline & & & Chemical Weapons Convention \\
\hline \multirow{5}{*}{ Illegal immigration } & Legal/political method & $\begin{array}{l}\text { Immigration laws for reducing illegal } \\
\text { immigration }\end{array}$ & $\begin{array}{l}\text { Secure America Through Verification } \\
\text { and Enforcement Act of } 2011\end{array}$ \\
\hline & \multirow{2}{*}{ Comprehensive methods } & Border enforcement & $\begin{array}{l}\text { Hiring more border control agents, } \\
\text { providing tools for border protection }\end{array}$ \\
\hline & & Restrictions on illegal employments & $\begin{array}{l}\text { Verification of an employee's legal } \\
\text { status }\end{array}$ \\
\hline & \multirow[b]{2}{*}{ Physical method } & Construction of border barriers & Mexico-United States barrier \\
\hline & & $\begin{array}{l}\text { Increased construction of detention } \\
\text { facilities \& detention of immigrants }\end{array}$ & $\begin{array}{l}\text { U.S. President Trump's executive } \\
\text { orders on border security }\end{array}$ \\
\hline $\begin{array}{l}\text { Epidemics of socially } \\
\text { dangerous diseases }\end{array}$ & Legal/political method & Public health law & $\begin{array}{l}\text { Laws and regulations governing the } \\
\text { control of communicable diseases }\end{array}$ \\
\hline
\end{tabular}

https://digitalcommons.usf.edu/jss/vol13/iss2/4 D0I: https://doi.org/10.5038/1944-0472.13.2.1787

Fire threat to people \&
Economic method,

Technological method

Physical method
Cost-effective disease prevention and transmission strategy

Means of escape

Firefighting access \& provisions
Free or affordable immunization
Fire exits

Fire extinguishers, external water hydrants and internal stair risers 
Table 1. A Snippet of Taxonomic Framework of Security Methods (continued)

\begin{tabular}{|c|c|c|c|}
\hline $\begin{array}{l}\text { Source of Insecurity } \\
\text { (Type) }\end{array}$ & Method of Protection & Security Method (Type) & Instance of Security Method \\
\hline \multirow{2}{*}{$\begin{array}{l}\text { Epidemics of socially } \\
\text { dangerous diseases }\end{array}$} & Legal/political method & Public health law & $\begin{array}{l}\text { Laws and regulations governing the } \\
\text { control of communicable diseases }\end{array}$ \\
\hline & $\begin{array}{l}\text { Economic method, } \\
\text { Technological method }\end{array}$ & $\begin{array}{l}\text { Cost-effective disease prevention and } \\
\text { transmission strategy }\end{array}$ & Free or affordable immunization \\
\hline \multirow{5}{*}{$\begin{array}{l}\text { Fire threat to people \& } \\
\text { property }\end{array}$} & \multirow[b]{2}{*}{ Physical method } & Means of escape & Fire exits \\
\hline & & Firefighting access \& provisions & $\begin{array}{l}\text { Fire extinguishers, external water } \\
\text { hydrants and internal stair risers }\end{array}$ \\
\hline & Technological method & Fire detection \& warning & Fire detection/alarm system \\
\hline & \multirow{2}{*}{ Administrative method } & Emergency response & Staff fire drills \\
\hline & & Fire safety management & Fire systems testing \& maintenance \\
\hline \multirow{4}{*}{$\begin{array}{l}\text { Unauthorized access to } \\
\text { office facilities }\end{array}$} & \multirow[b]{2}{*}{ Physical method } & Physical access control & Mechanical/electronic locks \\
\hline & & Authentication/authorization & $\begin{array}{l}\text { Authentication via ID picture \& } \\
\text { guard verification }\end{array}$ \\
\hline & \multirow[b]{2}{*}{ Technological method } & Visual monitoring & Closed circuit television \\
\hline & & Authentication/authorization & $\begin{array}{l}\text { Authentication and authorization } \\
\text { via two-factor biometric }\end{array}$ \\
\hline \multirow{4}{*}{$\begin{array}{l}\text { Information } \\
\text { loss/damage, data } \\
\text { breach }\end{array}$} & Physical method & Physical access restrictions & $\begin{array}{l}\text { Mechanical/electronic locks for file } \\
\text { cabinets, computers and phones }\end{array}$ \\
\hline & \multirow{2}{*}{ Technological method } & Data protection & $\begin{array}{l}\text { Encryption of data (including } \\
\text { cloud data) }\end{array}$ \\
\hline & & Information access control & $\begin{array}{l}\text { Two-factor identification of } \\
\text { accessing information }\end{array}$ \\
\hline & Administrative method & Background checks & $\begin{array}{l}\text { Employee background checks, } \\
\text { vendor background checks }\end{array}$ \\
\hline
\end{tabular}

Source: Author 
Table 2 shows an example snippet of the integrated taxonomy.

Table 2. Security methods taxonomy connected with security taxonomy (an example)

\begin{tabular}{llll}
\hline $\begin{array}{l}\text { Source of } \\
\text { Insecurity } \\
\text { (Type) }\end{array}$ & Subject/Scope & Object & $\begin{array}{l}\text { Security } \\
\text { Category/Subcategory }\end{array}$ \\
\hline $\begin{array}{l}\text { Illegal } \\
\text { immigration }\end{array}$ & Nation & $\begin{array}{l}\text { National } \\
\text { border }\end{array}$ & $\begin{array}{l}\text { National (border) } \\
\text { security }\end{array}$ \\
\hline $\begin{array}{l}\text { Fire threat to } \\
\text { people \& } \\
\text { property }\end{array}$ & Organization/Institution & $\begin{array}{l}\text { People \& } \\
\text { property }\end{array}$ & Business security \\
\cline { 2 - 4 } & Individual \& family & $\begin{array}{l}\text { People \& } \\
\text { property }\end{array}$ & $\begin{array}{l}\text { Family/personal } \\
\text { security }\end{array}$ \\
\hline & Individual \& Family & Information & $\begin{array}{l}\text { Personal information } \\
\text { security }\end{array}$ \\
\cline { 2 - 4 } $\begin{array}{l}\text { Information } \\
\text { loss/damage, } \\
\text { data breach }\end{array}$ & Organization/Institution & Information & $\begin{array}{l}\text { Institutional } \\
\text { information security }\end{array}$ \\
\cline { 2 - 4 } & Nation & Information & $\begin{array}{l}\text { National information } \\
\text { security }\end{array}$ \\
\hline
\end{tabular}

Source: Author

The Space (S) and Time (T) facets introduced in the author's previous work can be added to the security methods taxonomic framework when needed. ${ }^{6}$ Table 1 and Table 2 can be used to classify information resources about security. For example, suppose one would like to categorize an article about "President Trump's executive orders on immigration and refugees." It can have two categories: U.S. National Security at the United States/Mexico border in 2019 (according to Table 2), and about security method - physical method - increased construction of detention facilities \& detention of immigrants - at United States/Mexico border in 2019 (according to Table 1). 47 


\section{Conclusion and Future Work}

There is no comprehensive taxonomy of security methods except that the ACM Computing Classification System has a section of Security and Privacy, which includes some security methods. Four books (Hemphill's Modern Security Methods for protecting personal and business security, Young's Metrics and Methods for Security Risk Management in the government/corporate security domain, John Fay's Contemporary Security Management introducing all necessary physical and IT security measures in government/corporate environment, and James Border and Eugene Tucker's Risk Analysis and the Security Survey introducing a security survey checklist) can be considered as taxonomic introductions to security methods. ${ }^{48}$ Based on facet analysis and a tetra-facet model of security developed in the author's previous study, the author developed a taxonomic framework of security methods using two facets of security (that is, Source of Insecurity, and Method of Protection), whereas the Source of Insecurity is the leading facet. The article demonstrates the application of facet analysis to the hypernym concept of a subject term (that is, security) instead of the subject term itself (that is, protection of security, or security methods) in taxonomy development. The taxonomic framework of security methods can be integrated with the security taxonomic framework developed in the author's previous study. The two taxonomic frameworks can be used for security management and the management of information resources related to security and security methods.

In the future, the taxonomic framework of security methods needs to be evaluated by security experts. With this taxonomic framework, the author can study the impacts of certain security methods related to some complicated security events (such as the U.S. Department of Commerce's export control restrictions to Huawei). The relationships between the security methods and the reactions of the stakeholders can be organized and visualized using a topic map, which can be used to facilitate the understanding of the impacts of certain security methods taken for handling certain security concerns. 49 The cause of insecurity can also be added to Table 1 to categorize Security Method Type further. For example, illegal immigration can have both push reasons (such as poor economy in one's own country) and pull reasons (such as economic opportunities in a 
foreign country). The further categorization can enrich not only the Security Method Type but also the instance of Security Method.

\title{
Acknowledgement
}

\author{
The author would like to thank the anonymous reviewers for their \\ constructive suggestions and comments, which have been incorporated \\ into the article.
}

\section{Endnotes}

${ }^{1}$ Cecilia Kang and David E. Sanger, "Huawei Is a Target as Trump Moves to Ban Foreign Telecom Gear," The New York Times, May 15, 2019, https://www.nytimes.com/2019/05/15/business/huawei-ban-trump.html. ${ }^{2}$ Catalin Cimpanu, "Russia's New 'Disconnect from the Internet' Law is Actually about Surveillance," ZDNet.com, November 1, 2019, https://www.zdnet.com/article/russiasnew-disconnect-from-the-internet-law-is-actuallyabout-surveillance/. 3 Yejun Wu and Fansong Meng, "Categorizing Security for Security Management and Information Resource Management," Journal of Strategic Security 11, no.4 (2019): 7284, https://doi.org/10.5038/1944-0472.11.4.1694.

4 "Library of Congress Classification Outline," The Library of Congress, accessed December 20, 2019, https://www.loc.gov/catdir/cpso/lcco/; "Library of Congress Subject Headings," The Library of Congress, accessed December 20, 2019, https://www.loc.gov/aba/publications/FreeLCSH/freelcsh.html; "The 2012 ACM Computing Classification System - Introduction," Association for Computing Machinery, accessed December 20, 2019, https://www.acm.org/publications/class-2012; "Social Security Menu," The U.S. Social Security Administration, accessed December 20, 2019, https://www.ssa.gov/site/menu/en/; "What We Do," The World Bank, accessed December 20, 2019, http://www.worldbank.org/; "Topics," The Department of Homeland Security, accessed December 20, 2019, https://www.dhs.gov/topics; A. Chakrabarti \& G. Manimaran, "Internet Infrastructure Security: A Taxonomy," IEEE Network: The Magazine of Global Internetworking 16, no.6 (2002): 13-21, https://doi.org/10.1109/MNET.2002.1081761.

5 Yejun Wu and Fansong Meng, "Creating a Security Methods Taxonomy for Information Resource Management," In Lecture Notes in Computer Science 11853, eds. Jatowt A., Maeda A. \& Syn S. (Springer, Cham, 2019), 293-297.

${ }^{6}$ Yejun Wu and Fansong Meng, "Categorizing Security for Security Management and Information Resource Management," 72-84; Yejun Wu and Fansong Meng, "Creating a Security Methods Taxonomy for Information Resource Management,” 293-297. 7 "The 2012 ACM Computing Classification System - Introduction," Association for Computing Machinery, accessed December 20, 2019, https://www.acm.org/publications/class-2012.

8 Yejun Wu and Fansong Meng, "Categorizing Security for Security Management and Information Resource Management," 72-84.

9 Yejun Wu and Fansong Meng, "Categorizing Security for Security Management and Information Resource Management," 72-84; Yejun Wu and Fansong Meng, "Creating a Security Methods Taxonomy for Information Resource Management," 293-297.

${ }^{10}$ Horrigan B. et al., "Security Studies," In Encyclopedia of Violence, Peace and Conflict, $2^{\text {nd }}$ Edition, ed. Kurtz, L. 
(Elsevier Science \& Technology, 2008), https://search.credoreference.com/content/entry/estpeace/security_studies/o. ${ }^{11}$ Yejun $\mathrm{Wu}$ and Fansong Meng, "Categorizing Security for Security Management and Information Resource Management," 72-84.

${ }^{12}$ Carl S. Young, Metrics and Methods for Security Risk Management (Elsevier Inc., 2010): 55 .

${ }^{13}$ Yejun $\mathrm{Wu}$ and Fansong Meng, "Categorizing Security for Security Management and Information Resource Management," 72-84.

14 Charles F. Hemphill, Jr. Modern Security Methods (Englewood Cliffs, New Jersey: Prentice-Hall, Inc., 1979).

15 Carl S. Young, Metrics and Methods for Security Risk Management, 55.

${ }^{16}$ John Fay, Contemporary Security Management, 3rd Edition (ButterworthHeinemann, 2010).

${ }^{17}$ James F. Broder and Eugene Tucker, Risk Analysis and the Security Survey, 4th

Edition (Butterworth-Heinemann, 2012).

${ }^{18}$ Yejun Wu and Fansong Meng, "Categorizing Security for Security Management and Information Resource Management," 72-84.

19 A. Chakrabarti \& G. Manimaran, "Internet Infrastructure Security: A Taxonomy," 13-21. 20 "10 Data Security Methods for Protecting Your Small Business," Pekin Insurance, accessed December 20, 2019, http://blog.pekininsurance.com/business/data-securitymethods-for-protecting-your-small-business.

${ }^{21}$ Yejun $\mathrm{Wu}$ and Fansong Meng, "Categorizing Security for Security Management and Information Resource Management," 72-84.

${ }^{22}$ Douglas J. Foskett, "Facet Analysis," in Encyclopedia of Library and Information Science, ed. Miriam A. Drake (New York: Marcel Dekker, Inc., 2003), https://www.taylorfrancis.com/books/9780849397110/chapters/10.1081/E-ELIS3120008985.

23 Elaine Svenonius, The Intellectual Foundation of Information Organization (Cambridge, MA: MIT Press, 2000), 139.

24 Douglas Foskett, "Facet Analysis," in Encyclopedia of Library and Information Sciences, Third Edition, eds. Marcia J. Bates and Mary Niles Maack (Boca Raton: CRC Press, 2009): 1819.

25 Shiyali Ramamrita Ranganathan, Colon Classification, 7th Edition: A Practical Introduction (Bangalore: Sarada Ranganathan Endowment for Library Science, 1987). ${ }^{26}$ Yejun Wu and Fansong Meng, "Categorizing Security for Security Management and Information Resource Management," 72-84.

27 Yejun Wu and Fansong Meng, "Categorizing Security for Security Management and Information Resource Management," 72-84.

28 Douglas Foskett, "Facet Analysis."

29 Elaine Svenonius, The Intellectual Foundation of Information Organization, 139.

$3^{30}$ Yejun Wu and Fansong Meng, "Creating a Security Methods Taxonomy for Information Resource Management,” 293-297.

${ }^{31}$ Yejun Wu and Fansong Meng, "Categorizing Security for Security Management and Information Resource Management," 72-84.

${ }^{2}$ Yejun Wu and Fansong Meng, "Creating a Security Methods Taxonomy for Information Resource Management," 293-297.

33 Yejun Wu and Fansong Meng, "Creating a Security Methods Taxonomy for Information Resource Management," 293-297.

34 Carl S. Young, Metrics and Methods for Security Risk Management, 47.

35 Carl S. Young, Metrics and Methods for Security Risk Management, 17.

${ }^{36}$ Carl S. Young, Metrics and Methods for Security Risk Management, 16.

37 Carl S. Young, Metrics and Methods for Security Risk Management, 45.

$3^{8}$ Carl S. Young, Metrics and Methods for Security Risk Management, 16.

39 Carl S. Young, Metrics and Methods for Security Risk Management, 16.

${ }^{40}$ Yejun Wu and Fansong Meng, "Categorizing Security for Security Management and Information Resource Management," 72-84. 
${ }^{41}$ Yejun Wu and Fansong Meng, "Creating a Security Methods Taxonomy for Information Resource Management,” 293-297.

42 Yejun Wu and Li Yang, "Construction and Evaluation of an Oil Spill Semantic Relation Taxonomy for Supporting Knowledge Discovery," Knowledge Organization 42, no.4 (2015): 222-231, https://doi.org/ 10.5771/o943-7444-2015-4-222.

43 Carl S. Young, Metrics and Methods for Security Risk Management, 57.

44 Carl S. Young, Metrics and Methods for Security Risk Management, 57.

45 Yejun Wu and Fansong Meng, "Categorizing Security for Security Management and Information Resource Management," 72-84.

46 Yejun Wu and Fansong Meng, "Categorizing Security for Security Management and Information Resource Management," 72-84.

47 "President Trump's Executive Orders on Immigration and Refugees," The Center for Migration Studies, accessed December 20, 2019, https://cmsny.org/trumps-executiveorders-immigration-refugees/.

${ }^{48}$ Charles F. Hemphill, Jr. Modern Security Methods; Carl S. Young, Metrics and Methods for Security Risk Management.

49 Yejun Wu, ed., Oil Spill Impacts: Taxonomic and Ontological Approaches (Boca Raton, Florida: CRC Press, 2016), 7-9. 